\title{
Kemoradyoterapi ile Tedavi Edilen Lokal İleri Nazofarinks Karsinomlu Olgularda Bcl-2 ve CD9 Ekspresyonunun Prognostik Önemi
}

\author{
Prognostic Significance of BCL-2 and CD9 Expression in Cases with Locally Advanced \\ Nasopharinks Carcinoma which Treated by Chemoradiotherapy
}

Selahattin MENTES ${ }^{1}$, Ozlem CANOZ ${ }^{2}$, Serdar SOYUER ${ }^{3}$

\footnotetext{
${ }^{1}$ Department of Radiation Oncology, Health Sciences University, Adana City Hospital, Adana, Turkey

${ }^{2}$ Department of Pathology, Erciyes University Faculty of Medicine, Kayseri, Turkey

${ }^{3}$ Department of Radiation Oncology, Acıbadem Hospital, Kayseri, Turkey
}

\section{Özet}

Amaç: Nazofarins kanserleri, diğer baş ve boyun kanserlerinden etiyolojik, epidemiyolojik, histopatolojik özellikler, biyolojik davranış ve tedavileri aç1sından önemli farklılıklar gösterir. Bu çalışmada amacımız kemoradyoterapi ile tedavi edilen lokal ileri evre nazofarinks kanserli hastalarda Bcl-2 ve CD9 ekspresyonunun prognostik önemini göstermektir.

Gereç ve Yöntemler: Araştırmaya Erciyes Üniversitesi Onkoloji Hastanesinde 18 yaşından büyük kemoradyoterapi ile tedavi edilen lokal ileri evre 40 nazofarinks kanserli hasta dahil edildi. Bu hastaların parafin bloklarında, immünohistokimyasal yöntemle CD9 ve Bcl-2 araştırıldı ve diğer klinikopatolojik parametrelerle karşılaştırıldı. Hastaların sağkalım, lokal kontrol, hastalıksız sağkalım ve prognostik faktörleri değerlendirildi.

Bulgular: Bcl-2 pozitif ve negatif vakalar arasında 5 yıllık hastalıksız sağkalım, genel sağkalım ve lokal kontrol açısından anlamlı fark bulunmadı (sırasıyla $\mathrm{p}=0.811, \mathrm{p}=0.845$ ve $\mathrm{p}=0.442$ ). Genel sağkalım, lokal kontrol ve hastalıksız sağkalım için prognostik faktörler olarak Bcl-2 pozitifliği veya negatifliğini anlamlı gösteremedik ( $\mathrm{p}>0.05$ ). CD9 pozitif grupta 5 yıllık lokal kontrol açısından istatistiksel olarak anlamlı bir fark bulundu ( $\mathrm{p}=0.047)$.

Sonuç: Yaptığımız çalışmada, nazofarinks kanserli hastalarda CD9'un prognostik önemini gösterdik. Ancak Bcl-2'nin prognostik değeri olup olmadığını gösteremedik.

Anahtar Kelimeler: Nazofarinks kanseri, Kemoradyoterapi, Bcl-2, CD9

\section{Abstract}

Objectives: Nasopharynx cancers differ significantly from other head and neck cancers in terms of etiological, epidemiological, histopathological features, biological expression in patients with locally advanced nasopharynx cancer treated with chemoradiotherapy behavior and treatments. In this study, we aimed to show the prognostic significance of Bcl-2 and CD9.

Material and Methods: Forty patients with locally advanced nasopharynx cancer who were older than 18 years of age and were treated with chemoradiotherapy at Erciyes University Oncology Hospital were included in the study. In these patients, CD9 and Bcl-2 were investigated by paraffin immunohistochemical method and compared with other clinicopathological parameters. Survival, local control, disease-free survival and prognostic factors of the patients were also evaluated.

Results: No significant difference was found between Bcl-2 positive and negative cases in terms of 5-year disease-free survival, overall survival and local control ( $p=0.811, p=0.845$ and $p=0.442$, respectively). We could not show significant Bcl-2 positivity or negativity as prognostic factors for overall survival, local control and disease-free survival ( $\mathrm{p}>0.05)$. A statistically significant difference was found in the CD9 positive group in terms of 5-year local control $(\mathrm{p}=0.047)$.

Conclusion: In our study, we showed the prognostic importance of CD9 in patients with nasopharyngeal cancer. However, we could not show whether Bcl-2 has a prognostic value or not.

Keywords: Nasopharyngeal carcinoma, Chemoradiotherapy, Bcl-2, CD9

Yazışma Adresi: Selahattin MENTEŞ, Sağlık Bilimleri Üniversitesi, Adana Şehir Hastanesi, Radyasyon Onkolojisi Kliniği, Adana, Türkiye, Telefon: 03224559000, Mail: selahattinmentes01@gmail.com

ORCID No (Sirasıly): 0000-0002-1371-7356, 0000-0002-0200-6970, 0000-0003-4808-3071

Geliş tarihi: 06.07.2020

Kabul tarihi: 09.10 .2020

DOI: $10.17517 / \mathrm{ksutfd} .764879$ 


\section{INTRODUCTION}

Nasopharyngeal cancers (NPCs) exhibit important differences from other head and neck cancers in terms of etiological, epidemiological and histopathological features, biological behavior and treatment (1). As they have been diagnosed in advanced stages, 10 -years survival is about $40 \%$, when average of all stages were considered (2). Thus, ongoing efforts are made to seek factors, which can be important for early diagnosis, prediction of prognosis and novel therapeutic strategies (3).

In recent years, it has been emphasized on interactions between differentiation and biological behaviors of tumors and oncogenes; since, it is possible to utilize these relationships as prognostic markers. It was shown that high rates of angiogenesis could be an important prognostic factor for distant metastasis, Overall survival (OS) and disease-free survival (DFS) $(4,5)$.

Apopitosis has a key role in the development of tumors. $\mathrm{Bcl}-2$, which is a gene that enables resistance to apopitotic stimulants, is found at $\mathrm{t}(14: 18)$ translocation in low-grade $\mathrm{B}$ cell non-Hodgkin lymphoma. Thereby, $\mathrm{Bcl}-2$ gene can provide information about prognosis. 16 homologues of Bcl-2 was identified in human being (5). While some members (Bcl-2, $\mathrm{Bcl}-\mathrm{xL}, \mathrm{Bcl}-\mathrm{W}$ ) inhibit apopitosis, others (Bak, Bad, Bax, Bid, Bik) promote (6).

CD9 (MRP-1) was first described as a transmembrane glycoprotein. It is produced at hematopoietic and non-hematopoietic tissues. Physiological characteristics are not fully understood. Anti-CD9 antibodies cause platelet activation by type II IgG Fc receptor. CD9 is found to be related to tumor cell proliferation and metastasis. Presence of CD9 is considered as a positive prognostic factor (7).

There is limited number of studies regarding Bcl-2 in the literature. This study is present regarding CD9 as prognostic factor in NPCs. In this study, it was aimed to determine the effects of Bcl-2, an anti-apopitotic molecule, and CD9, which is linked to cell proliferation and cell mobility, on OS, local control and DFS and to assess prognostic factor in cases with locally advanced nasopharyngeal carcinoma which were treated by concurrent-cisplatin based chemoradiotherapy (CRT).

\section{MATERIAL and METHODS}

\section{Patients}

This study includes 40 cases with locally advanced nasopharyngeal carcinoma which were treated by concurrent CRT with cisplatin between January 2004 and December 2009. The study was planned according to the principles of the Helsinki Declaration. Ethical approval was obtained from Erciyes University Faculty of Medicine on February 18.02.2011.

\section{Chemoradiotherapy}

All cases in the study were underwent concurrent CRT with weekly cisplatin. During radiotherapy (RT) cisplatin 20 $\mathrm{mg} / \mathrm{m}^{2}$ were administered concomitantly at the first day of the week. Treatment volume was arranged as two reciprocal field and a supra field which encompass nasopharynx, adjacent parapharyngeal tissues with a border of 1-2 cm and all neck lymphatic. Spinal cord was protected after $46 \mathrm{~Gy}$. Tumor dose was estimated according to multiple-isocenter field. Total dose of 70 Gy was administered on a schedule 2 Gy per fraction, per day, 5 days per week in 35 fractions. Therapy process were administered by using 6-18 MV photon energy and $9 \mathrm{MeV}$ electron energy via a linear accelerator (LINAC).

\section{Immunohistochemical Staining of CD9 (MRP-1) and Bcl-2}

Paraffin-blocked tumor tissue samples of patients were obtained from archive of Pathology Department. Paraffin block cassette is mounted to block holder of microtome device. Tissue mass is reached by drilling anterior surface of tissue. After cutting $4 \mu$ thickened tissues, sections are delivered to $43^{\circ} \mathrm{C}$ water. Then, sections are loaded to slides.

\section{Immunohistochemical Assessment}

When assessing immunohistochemical staining, staining within tissue is considered for positive control. Tonsil tissue was used as positive control tissue for Bcl-2 and CD9. All above-mentioned staining procedures were performed after staining and assessing tonsil tissue under microscope.

\section{Immunohistochemical Assessment of Bcl-2}

For Bcl-2, it is considered as positive, when there is a cytoplasmic staining in more than $25 \%$ of all tumor cells at $10 \mathrm{x}$ magnification, otherwise it was considered as $\mathrm{Bcl}-2$ negative.

\section{Immunohistochemical Assessment of CD9 (MRP-1)}

For CD9, it is considered as positive, when there is a cytoplasmic staining in more than $5 \%$ of all tumor cells at $10 \mathrm{x}$ magnification, otherwise it was considered as $\mathrm{Bcl}-2$ negative.

\section{Statistical Analysis}

Data were analyzed by using SPSS version 15.0 for Windows. Normal distribution of data is assessed by One-Sample Kolmogorov-Smirnov test. As no median value was reached, survival data were expressed as means. Chi-square test was used to compare quantitative variables. Survival analysis was performed by using Kaplan-Meier method and statistical difference was assessed by using log rank test. Cox regression analysis was used to assess risk factors including gender (male or female), age ( $\leq 40$ years or $>40$ years), T state (T1-2 or T3-4), N state (N0 or N1-3), stage (Stage II-III or Stage IVA-IVB), Bcl-2 (positive or negative) and CD9 (positive or negative) as prognostic factors. $\mathrm{p}<0.05$ was considered as statistically significant. 


\section{RESULTS}

Table 1 shows characteristic of cases in terms of whole group and according to $\mathrm{Bcl}-2$ and $\mathrm{CD} 9$ state. Median age was 45 (range; 23-72 years) years. There were 15 (37.5\%) Bcl-2 negative cases, while $25(62.5 \%)$ cases were positive; and there were 21 (52.5\%) CD9 negative cases, whereas 19 (47.5\%) cases were positive. When groups according to $\mathrm{Bcl}-2$ and CD9 state (positive or negative) were compared in terms of age, gender, $\mathrm{T}$ state, $\mathrm{N}$ state and stage (except $\mathrm{N}$ state in CD9; $\mathrm{p}=0.017$ ), no statistically significant difference was found between groups ( $\mathrm{p}>0.05)$.

\begin{tabular}{|c|c|c|c|c|c|c|c|}
\hline \multirow[t]{2}{*}{ Characteristics } & \multirow[t]{2}{*}{ Total } & \multicolumn{3}{|l|}{ BCL-2 } & \multicolumn{3}{|l|}{ CD9 } \\
\hline & & $(-)$ & $(+)$ & $p$ & $(-)$ & $(+)$ & $p$ \\
\hline$N$ & $40(100)$ & $15(37,5)$ & $25(62.5)$ & & $21(52.5)$ & $19(47.5)$ & \\
\hline $\begin{array}{l}\text { Age } \\
\text { (median,range) }\end{array}$ & $45(23-72)$ & $44(23-72)$ & $49(27-72)$ & 0.37 & $44(27-72)$ & $49(23-72)$ & 0.346 \\
\hline $\begin{array}{l}\text { Gender } \\
\text { Female } \\
\text { Male }\end{array}$ & $\begin{array}{l}10(25) \\
30(75)\end{array}$ & $\begin{array}{l}2(5) \\
13(32.5)\end{array}$ & $\begin{array}{l}8(20) \\
17(42.5)\end{array}$ & 0.18 & $\begin{array}{l}6(15) \\
15(37.5)\end{array}$ & $\begin{array}{l}4(10) \\
15(37.5)\end{array}$ & 0.583 \\
\hline $\begin{array}{l}\text { T classification } \\
\text { T1 } \\
\text { T2 } \\
\text { T3 } \\
\text { T4 }\end{array}$ & $\begin{array}{l}2(5) \\
14(35) \\
10(25) \\
14(35))\end{array}$ & $\begin{array}{l}1(5) \\
7(\% 17.5) \\
3(7.5) \\
4(10)\end{array}$ & $\begin{array}{l}1(2.5) \\
7(17.5) \\
7(17.5) \\
10(25)\end{array}$ & 0.61 & $\begin{array}{l}1(2.5) \\
4(10) \\
8(20) \\
8(20)\end{array}$ & $\begin{array}{l}1(2.5) \\
10(25) \\
2(5) \\
6(15)\end{array}$ & 0.095 \\
\hline $\begin{array}{l}\text { N classification } \\
\text { N0 } \\
\text { N1 } \\
\text { N2 } \\
\text { N3 }\end{array}$ & $\begin{array}{l}11(27.5) \\
12(30) \\
13(32.5) \\
4(10)\end{array}$ & $\begin{array}{l}3(7.5) \\
5(12.5) \\
5(12.5) \\
2(5)\end{array}$ & $\begin{array}{l}8(20) \\
7(17.5) \\
8(20) \\
2(5)\end{array}$ & 0.83 & $\begin{array}{l}6(15) \\
3(7.5) \\
11(27.5) \\
1(2.5)\end{array}$ & $\begin{array}{l}5(12.5) \\
9(22.5) \\
2(5) \\
3(7.5)\end{array}$ & 0.017 \\
\hline $\begin{array}{l}\text { Stage } \\
\text { II } \\
\text { III } \\
\text { IVA } \\
\text { IVB }\end{array}$ & $\begin{array}{l}10((25) \\
12(30) \\
14(35) \\
4(10)\end{array}$ & $\begin{array}{l}5(12.5) \\
4(10) \\
4(10) \\
2(5)\end{array}$ & $\begin{array}{l}5(12.5) \\
8(20) \\
10(25) \\
2(5)\end{array}$ & 0.683 & $\begin{array}{l}3(7.5) \\
9(22.5) \\
8(20) \\
1(2.5)\end{array}$ & $\begin{array}{l}7(17.5) \\
3(7.5) \\
6(15) \\
3(7.5)\end{array}$ & 0.112 \\
\hline
\end{tabular}

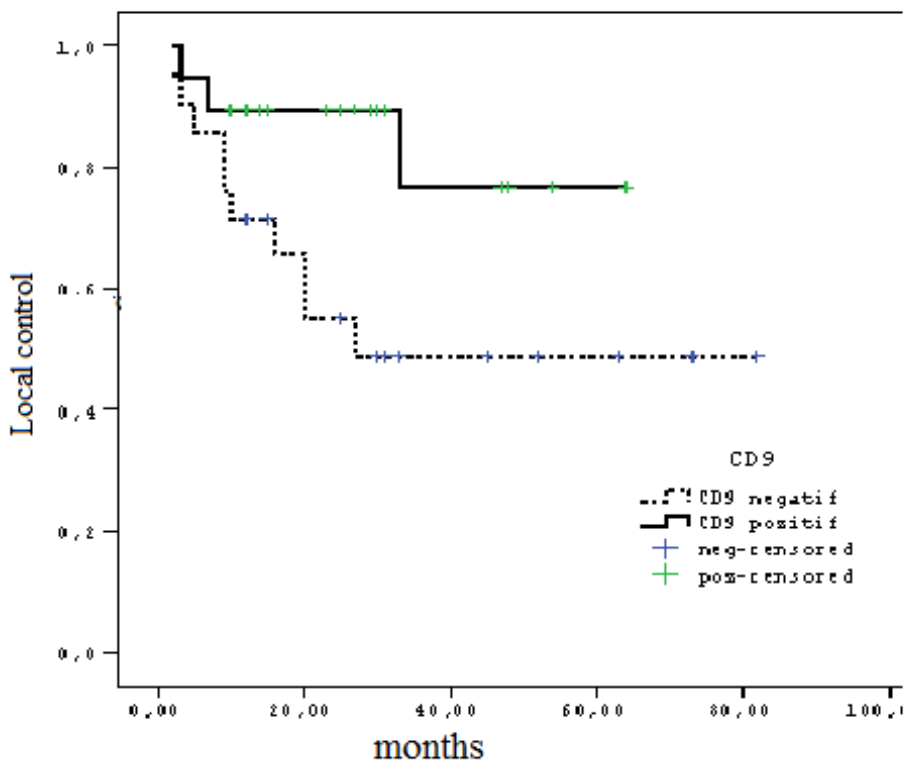

Figure 1. Local control curve according to CD9 negative $(\mathrm{n}=21)$ and positive $(\mathrm{n}=19)$ groups $(p=0.047)$. 
Mean follow-up was 27.5 (range; 2-82 months) months. Mean OS was found as $61.00 \pm 5.55$ months, whereas local control duration and DFS as $56.00 \pm 5.76$ months and $55 . \pm 05.75$ months, respectively. In Bcl-2 negative and positive groups, OS, local control duration and DFS were found as 66.81 versus 45.61 months, 58.24 versus 44.04 months and 52.90 versus 44.70 months, respectively. Although survival was numerically higher in Bcl-2 negative group, no statistically significant difference was found. In CD9 positive and negative groups, difference in OS (53.02 versus 56.72 months; $\mathrm{p}=0.060$ ) was found as close to statistical significance. A statistically significant difference was found in terms of local control (46.58 vs. 53.82 months; $\mathrm{p}=0.047$ ) (Figure 1). No statistically significant difference was found in DFS (46.39 vs. 51.89 months; $\mathrm{p}=0.127$ ) (Table 2).

Table 2. 5-years survival rates of the cases.

\begin{tabular}{|c|c|c|c|c|c|c|c|}
\hline \multirow[t]{2}{*}{ Survivals } & \multirow[t]{2}{*}{ Total } & \multicolumn{3}{|c|}{ BCL-2 } & \multicolumn{3}{|c|}{ CD9 } \\
\hline & & $(-)$ & $(+)$ & $p$ & $(-)$ & $(+)$ & $p$ \\
\hline os & & $\% 78$ & $\% 64$ & 0.811 & $\% 57$ & $\% 81$ & 0.127 \\
\hline Local control & & $\% 66$ & $\% 58$ & 0.845 & $\% 49$ & $\% 77$ & 0.047 \\
\hline Disease-free survival & & $\% 59$ & $\% 58$ & 0.442 & $\% 49$ & $\% 79$ & 0.060 \\
\hline
\end{tabular}

Table 3. Univariate analysis of risk factors in the OS.

\begin{tabular}{|l|l|l|}
\hline Risk Factors & $\begin{array}{l}\text { Univariate Analysis } \\
\text { OR (95\% CI) p value }\end{array}$ & 0.546 \\
\hline Gender (Female or Male) & $1.52(0.39-5.91)$ & 0.477 \\
\hline Age ( $\leq \mathbf{4 0}$ or $>\mathbf{4 0})$ & $1.63(0.42-6.39)$ & 0.078 \\
\hline T classification (T1-2 or T3-4) & $6.42(0.81-50.88)$ & 0,404 \\
\hline N classification (N0 or N1-3) & $1.94(0.41-9.18)$ & 0.135 \\
\hline Stage (Stage 1-2 or 3-4Mo) & $2.81(0.72-10.90)$ & 0.448 \\
\hline Bcl-2 (Negative or Positive) & $1.69(0.43-6.57)$ & 0.082 \\
\hline CD9 (Negative or Positive) & $3.95(0.86-18.61)$ & \\
\hline
\end{tabular}

No significant difference was detected in OS, local control and DFS in univariate and multivariate analysis, which were performed for assessment of prognostic factor according to risk factor including Bcl-2 and CD9 ( $p>0.05)$. Table 3 shows only univariate data for OS. According to this results, a trend was detected in T state (T1-2 or T3-4) and CD9 state (positive or negative) towards significant difference ( $\mathrm{p}=0.078$ and $\mathrm{p}=0.082$, respectively)

\section{DISCUSSION}

NPCs remain to be an important health issue, although good outcomes are provided by advancing RT techniques and addition of chemotherapy in recent years. In NPCs, factors affecting prognosis have been assessed by patient, disease and treatment parameters and nowadays it has been emphasized on interactions between differentiation and bi- 
ological behavior of tumors and oncogenes; and on utilizing these relationships as prognostic predictors (8).

$\mathrm{Bcl}-2$ and $\mathrm{Bcl}-2$ gene family are the major genes that regulates apopitosis. Bcl-2 can enhance cell survival and inhibit apopitosis. Theoretically, Bcl-2 gene is expected to cause resistance to treatment and poor prognosis via two mechanisms: preventing normal apopitosis resulting with accelerated accumulation of tumor cells and blocking treatment-related apopitosis regardless than treatment type (9).

Positive Bcl-2 expression was reported 70\% in breast cancers, $30-60 \%$ in prostate cancers and $90 \%$ in colorectal cancers. In a study with 46 NSCLC (non-small lung cancer) cases by Yilmaz et al., 37 cases (80.4\%) were found as negative, while 9 cases (19.6\%) as positive for Bcl-2. It was seen that Bcl-2 positive cases had better survival rate (25\% vs. $12 \%$ in adenocarcinoma) $(10,11)$. Whereas, in our study, we found that our patients with $\mathrm{Bcl}-2$ negative had better surveillance, although we did not find statistically significant.

In a study with malign melanoma, they found that Bcl-2 positivity was related to resistance to chemotherapy as well as poor prognosis (12).

There is a inconsistency regarding results on prognostic value of Bcl-2 expressions in head and neck cancers. In two distinct studies, it was shown that Bcl-2 over-expression was related to poor outcome and shorter survival in early stage squamous cell carcinoma of head and neck $(9,10)$. We obtained data similar to the research done by N. Azad and O. Gallo. Raybaud et al., found that $\mathrm{Bcl}-2$ positive cases were more resistant to therapy in a study in which response to treatment was assessed in cases with head and neck cancer, undergoing chemotherapy and RT (11). In a study, Csuka et al. evaluated p53, Bax and Bcl-2 in cases with head and neck cancers and found that positive $\mathrm{Bcl}-2$ enhanced resistance to therapy and caused poor prognosis (13). In a Bcl-2 study in patients with head and neck cancer by Akyol et al., proportion of Bcl-2 positive cases was found as $71 \%$ (14). No relationship was found between Bcl-2 positivity and survival or stage of the patients. In a study on cases with NPC by Sarac et al., it was demonstrated that, in statistical analysis, Bcl-2 positivity $(74 \% ; 26 / 35)$ was a factor that affects cervical lymph node metastasis , cranial nerve involvement and disease survival (15).

In a Bcl-2 study in cases with NPC by Vera-Sempere FJ et al., it was found that Bcl-2 positivity was associated to diagnosis of indifferentiated, but not age, gender or stage (16). Likewise other studies, no relationship was found between $\mathrm{Bcl}-2$ positivity and survival or stage (12-15)

Positivity rate were reported between $18 \%$ and $36 \%$ in early stage squamous cell carcinoma of head and neck (2). Bcl-2 positivity rate $(62.5 \%)$ in our study was found to be consistent in those studies, which reported positivity rate between 60\%-90\% in nasopharynx cancers (14-18). Given the outcome of OS (66.81 versus 45.61 months), local control (58.24 versus 44.04 months) and disease free survival (52.90 versus 44.70 months) in Bcl-2 negative and positive groups, however, it should be suggested that, in cases with NPC, Bcl2 positive patients had poorer prognosis and shorter survival in agreement with literature. In our study, unlike others, OS , local control and DFS was individually assessed in terms of age, gender, T state, $\mathrm{N}$ state and stage in cases with NPC. Additionally, we think that outcome will reach statistical significance in case of larger series or longer follow-up. Mhawech et al. performed a retrospective study on 153 patients with head and neck cancer, who previously received radiotherapy.

CD9 (MRP-1) is a member of transmembrane 4 super family and is accounted from cell proliferation, adhesion and motility (19). CD9 is present in hematopoietic tissues, platelets, pre-B cells, active $\mathrm{T}$ cell and granulocytes. Additionally, it is also expressed in non-hematopoietic tissues. Malignity suppression effect of CD9 occurs by, partly, inhibition of cell motility and induction of apoptosis $(19,20)$. When the preparations of the cases were assessed for CD9, it was found that $71 \%(n=108)$ was positive, while $29 \%(n=45)$ was negative for CD9. Five year DFS was significantly higher in CD9 positive patients than those negative for CD9 (19).

In a study on 146 patients with stage III colon cancer by Hashida et al., of the cases, $47 \%(n=69)$ found as CD9 positive, while $53 \%(n=77)$ as negative. In that study, it was seen that 3-years OS and DFS was higher in CD9 positive cases than CD9 negative ones $(\mathrm{p}<0.001)(20)$.

In a study including 45 patients with rectum cancer, it was reported that CD9 positivity might have a prognostic value in terms of local-regional recurrences, whereas no prognostic value was shown for CD9 state (positive or negative) regarding 5-years OS and disease-free survival (21).

In a study on 40 patients with pancreas cancer by Sho et al., 15 cases (38\%) were found as CD9 positive. One-year OS was found to be lower ( $0 \%$ vs.25.5\%, respectively) in CD9 negative patients. It was also seen that median survival was longer (397 vs. 226 days, respectively) in CD9 positive patients than CD9 negative ones (22).

In a study on 132 patients with pulmonary adenocarcinoma by Higashiyama et al., it was found that, of these cases, $67 \%(n=88)$ was CD9 positive while $33 \%(n=44)$ was CD9 negative. 5-years OS and DFS were found to be significantly higher in patients with CD9 positivity than those with CD9 negativity ( $\mathrm{p}=0.005$ and $\mathrm{p}<0.0001$, respectively (23).

In a study on 109 patients with breast cancer by Huang et al., 72 patients $(66 \%)$ were positive, whereas 34 patients (34\%) were negative for CD9. When 5-years OS was assessed, it was found to be higher in CD9 positive patients than CD9 negative ones ( $94.0 \%$ vs. $80.8 \%$, respectively; $p=0.038$ ) (23). It is seen in Figure 1 that patients with positive CD9 have a high local control.

Briefly, it was shown that CD9 positivity increased OS and DFS with all these studies including osteosarcoma and breast, lung, bladder, esophagus, prostate and head-neck cancers $(19,20,22-30)$. 
In our study, of the 40 cases with NPC, it was found that $47.5 \%(n=19)$ were positive, while $52.5 \%(n=21)$ were negative for CD9. As can be seen in Table 2, results were obtained in parallel with the results of the above researchers. As it was the first study with NPC cases, our results were compared to cancer studies including cases other than NPC. These results were in agreement with the results obtained from patients with head and neck tumors by Mhawech et al (16). (for CD9 positivity; $64 \%$ vs. $71 \%$, respectively), whereas there was a disagreement with those obtained from patients with colon cancer by Hashida et al (20). and from patients with pancreas cancer by M.Sho et al (22). (for CD9 positivity; 64\% vs. $47 \%$ and $38 \%$, respectively). In the present study, 5-years OS, local control and DFS rates were $81 \%, 77 \%$ and $79 \%$ in CD9 positive patients, respectively. Although there was no statistically significant difference between CD9 positive and negative patients $(\mathrm{p}=0.127)$, an obvious numerical superiority was noteworthy. When DFS was considered, it was found that results were close to statistical significance in CD9 positive cases $(\mathrm{p}=0.060)$. These results (higher survival in CD9 patients) were in agreement with results of 3-year survival obtained from patients with colon cancer by Hashida et al (20). results of 1-year survival obtained from patients with pancreas cancer by Sho et al (22). and results of 5-year DFS obtained from patients with head and neck cancer by Mhawech et al.(19).

When 5-years local control rate were considered, it was found as $77 \%$ in CD9 positive patients, whereas 49\% in CD9 negative patients. This difference was statistically significant $(\mathrm{p}=0.047)$. Although it was shown that CD9 positivity increased OS and DFS in literature, no comparison could be performed, as no study exists about the effects of CD9 positivity on local control. Because the fact, that CD9 enhanced local control, despite no contribution to OS and DFS in our study, can be explained by smaller sample size, we suggest that these values can be significant in larger studies. As seen in Table 3, it is seen that the important factor affecting Univariate analysis is nasopharyngeal cancer in the local advanced $\mathrm{T}$ stage.

We failed to demonstrate a prognostic value for Bcl-2 state (positive or negative) in patients with nasopharyngeal carcinoma regarding 5-year OS, local control and 5-year DFS. But it was thought that CD9 positivity might be important for local control in patients with nasopharyngeal carcinoma. To clearly observe a prognostic value for CD9 state (positive or negative) on patients with nasopharyngeal carcinoma regarding 5-year DFS, it was thought that there is a need for further studies with larger sample size. We failed to demonstrate whether or not CD9 state (positive and negative) have prognostic value.

In a conclusion, in our study no statistically significant results were found between survival and BCL2 in patients with NPC. However in patients with negative BCL2; OS, local control and DFS appear to be longer. In patients with CD9 positive; OS, local control and DFS appear to be longer as well. We showed the prognostic importance of CD9 in patients with nasopharyngeal cancer. However, we could not show whether Bcl-2 has a prognostic value or not. In our study, due to the small number of patients included in the research, we could not reach statistically significant results.

Conflict of Interest and Financial Status: The authors declare that there is no conflict of interest to declare. The author(s) received no specific funding for this work.

Research Contribution Rate Statement Summary: The authors declare that, they have contributed equally to the manuscript.

\section{REFERENCES}

1. Perez C.A, Devineni V.R, Marcial-Vega V, Simpson J.R, Kucik N. Carcinoma of the nasopharynx: Factors affecting prognosis. Int J Radiation Oncology Biol Phys. 1992; 23: 271-280.

2. Ove R, Foote R.L, Bonner J.A. Nasopharyngeal Carcinoma. In: L.L. Gunderson, J.E. Teper (Eds.), Clinical Radiation Oncology, Second ed. Churchill Livingstone Philadelphia 2007; pp. 705726.

3. Liu Z, Li L, Yang Z, Luo W, Li X, Yang H, Yao K, Wu B, Fang W. Increased expression of MMP9 is correlated with poor prognosis of nasopharyngeal carcinoma. BMC Cancer. 2010;10:270.

4. Parton M, Dowsett M, Smitt I. Studies of apoptosis in breast cancer. BJM. 2001; 322: 1528-1532.

5. Matsuyama S, Llopis J, Deveraux Q.L., R.Y. Tsien, J.C. Reed. Changes in intramitechondrial and cytosolic pH: early events that modulate caspase activation during apopitosis. Nat Cell Biol. 2000; 2: 318-325.

6. Letai A.G. Diagnosing and exploiting cancer's to blocks in apoptosis. Nat Rev Cancer. 2008;8:121-132.

7. Boucheix C, Benoit P, Frachet P, Billard M, Worthington R.E., Gagnon J et al. Molecular Cloning of CD9 Antigen. The Journal of Biological Chemistry. 1991;266:117-122.

8. Stricker T.P, Kumar V. Neoplasia. In: V. Kumar, A.K. Abbas, N. Fausto, J.C. Aster. Robbins and Cotran Pathologic Basis of Disease. Eighth ed. Saunders Elsevier, Philadelphia 2010; pp. 259330.

9. Azad N, Iyer A, Vallyathan V, Wang L, Castranova V, Stehlik C, et al. Role of oxidative-nitrosative stres- mediated $\mathrm{Bcl}-2$ regulation in apoptosis and malignant transformation. Ann N Y Acad Sci 2010;1203:1-6.

10. Gallo O, Bianchi S. Bcl-2 overexpression and smoking history in head and neck cancer. J Natl Cancer Inst 87 1995;1024-1025.

11. Rayboud H, Odin G, Fafet A, Santini J, Monteil RA. Genic alteration in oral and head and neck squamous cell carcinomas; analysis of international literature. Pathol Biol. 2003; 51:176184.

12. Tas, D. Duranyıldız, A. Argon, H. Oğuz, H. Çamlıca, V. Yasasever, et al. Serum Bcl-2 and survivin levels in melanoma. Melanoma Res. 2004 ;14(6):543-6.

13. Csuka O, Remenar E, Koronczay K, Doleschall Z, Nemeth G. Predictive Value of p53, Bcl-2 and Bax in the Radiotherapy of Head and Neck Cancer. Pathology oncology Research 1997;3:37.

14. Akyol M. U, Akyol G, Gediklioğlu G, Hoşal Ş, Hoşal Ş, Ruacan Ş. Nazofarengeal Karsinomlarda Bcl-2 ve C-erb B2 ekspresyonu: Prognostik Önemleri and Klinikopatolojik Parametrelerle İlişkileri. K.B.B. ve Baş Boyun Cerrahisi Dergisi. 1997;5:74-77.

15. Saraç S, Akyol U, Kanbur B, Poyraz A, Akyol G, Yılmaz T, et al. Bcl-2 and LMP1 Expression in Nasopharyngeal Carcinomas. American Jounal of Otolaryngology. 2001;2:377-388. 
16. Vera-Sempere F. J, Burgos J.S, Botella M.S, Morera C. Immunohistochemical expression of $\mathrm{Bcl}-2$ oncoprotein in EBV-associated nasopharyngeal carcinoma correlated to histological type and survival. Histol Histopathol. 1997;12(1):9-18.

17. QY. Liu , AJ. Han, SY. You, Y. Dong, QX. Yang, JH. Wu, MF. Li. Correlation of Epstein-Barr virus-encoded latent membrane protein 1 (LMP1) to fascin and phosphorylated Stat3 in nasopharyngeal carcinoma. Ai Zheng. 2008;27(10):1070-6.

18. Yılmaz A, Savaş İ, Sak S. D, Güngör, Kaya A, Serinsöz E, et al. Distribution of Bcl-2 gene expression and its prognostic value in non-small cell lung cancer. Tüberküloz ve Toraks Dergisi. 2005; 53(4):323-329.

19. Mhawech P, Dulguerov P, Tschanz E, Verdan C, Ares C, Allal AS. Motility related protein-1 (MRP-/CD9) expression can predict disease-free survival in patients with squamous cell carcinoma of the head and neck. Brtish Journal of Cancer. 2004;90: 471-475.

20. Hashida H, Takabayashi A, Tokuhara T, Hattori N, Taki T, Hasegawa $\mathrm{H}$, et al. Clinical Significance of transmembrane $4 \mathrm{su}-$ perfamily in colon cancer. British Journal of Cancer. 2003;89; 158-167.

21. Kaplan S. Postoperatif konkomitan kemoradyoterapi ile tedavi edilen evre II-III rektum kanserli olgularda Nuclear Factor Kappa b Ve CD9/ motility releated protein-1'in prognostik önemi. Tipta Uzmanlık Tezi, Kayseri ; 2010.

22. Sho M, Adachi M, Taki T, Hashida H, Konishi T, Huang C, et al. Transmemrane 4 Superfamily as a prognostic factor in pancreatic cancer. Int. J. Cancer (Pred. Oncol). 1998;79,:509-516.

23. Higashiyama M, Doi O, Kodama K, Yokouchi H, Adachi M,
Huang C. L, et al. Immunohistochemically detected expression of motility-related protein-1 (MRP-1/CD9) in lung adenocarcinoma and its relation to prognosis. Int. J. Cancer (Pred. Oncol). 1997;74: 205-211.

24. Huang C, Kohno N, Ogawa E, Adachi M, Taki T, Miyake M. Correlation of Reduction in MRP-1/CD9 and KAI1/CD82 Expression with Recurrences in Breast Cancer Patients American Journal of Pathology. 1998 ;153:3.

25. Miyake M, Nakano K, LItoi S, Koh T, Taki T. Motility-related Protein-1 (MRP-1/CD9) Reduction as a Factor of Poor Prognosis in Breast Cancer. Cancer Research 1996 ;56(6):1244-9.

26. Higashiyama M, Tam T, Leki Y. Reduced Motility Related Protein-1(MRP-1/CD9) Gene Expression as a Factor of Poor Prognosis in Non-Small Cell Lung Cancer. Cancer Research. 1995;55: 6040-6044

27. Kubistaa B, Erovicb B. M, Klingera H, Sulzbacherc I, Trieba K. CD9 expression is not a prognostic factor in human osteosarcoma. Cancer Letters. 2004;209:105-110.

28. Mhawech P, Herrmann F, Coassin M, Guillou L, Iselin C. E. Motility-Related Protein 1 (MRP-1/CD9) Expression in Urothelial Bladder Carcinoma and its Relation to Tumor Recurrence and Progression American Cancer Society. 2003;8:11698.

29. Uchida S, Shimada Y, Watanabe G, Li Z. G, Hong T, Miyake M, et al. Motility-related protein (MRP-1/CD9) and KAI1/CD82 expression inversely correlate with lymph node metastasis in oesophageal squamous cell carcinoma. British Journal of Cancer. 1999;79(7/8):1168-1173.

30. Zvieriev V, Wang J. C, Chevrette M. Over-expression of CD9 does not affect in vivo tumorigenic or metastatic properties of human prostate cancer cells. Biochemical and Biophysical Research Communications. 2005;337:498-504. 